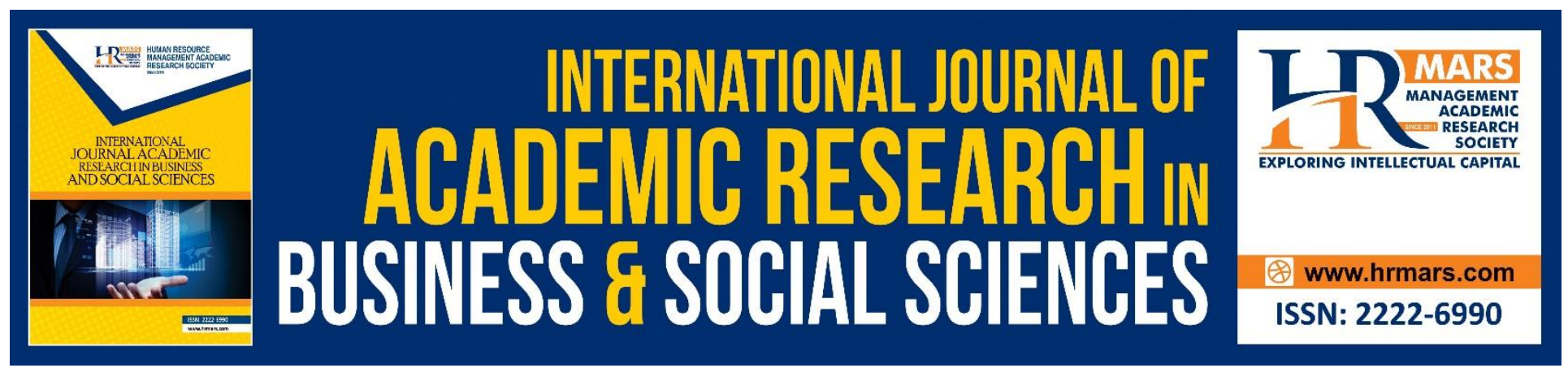

\title{
Assessing Student Teachers' Soft Skills Using Rubrics in E-portfolio
}

\author{
Azliza Muhammad, Othman Lebar, Siti Eshah Mokshein, Razmawaty \\ Mohamed, Salzuriawani Ridzwan \& Laily Fazlin Khairil
}

To Link this Article: http://dx.doi.org/10.6007/IJARBSS/v8-i10/5295

DOI: $10.6007 /$ IJARBSS/v8-i10/5295

Received: 03 Sept 2018, Revised: 08 Oct 2018, Accepted: 30 Oct 2018

Published Online: 02 Nov 2018

In-Text Citation: (Muhammad et al., 2018)

To Cite this Article: Muhammad, A., Lebar, O., Mokshein, S. E., Mohamed, R., Ridzwan, S., \& Khairil, L. F. (2018). Assessing Student Teachers' Soft Skills Using Rubrics in E-portfolio. International Journal of Academic Research in Business and Social Sciences, 8(10), 1245-1255.

\section{Copyright: (C) 2018 The Author(s)}

Published by Human Resource Management Academic Research Society (www.hrmars.com)

This article is published under the Creative Commons Attribution (CC BY 4.0) license. Anyone may reproduce, distribute, translate and create derivative works of this article (for both commercial and non-commercial purposes), subject to full attribution to the original publication and authors. The full terms of this license may be seen at: http://creativecommons.org/licences/by/4.0/legalcode

Vol. 8, No. 10, 2018, Pg. 1245 - 1255

Full Terms \& Conditions of access and use can be found at http://hrmars.com/index.php/pages/detail/publication-ethics 


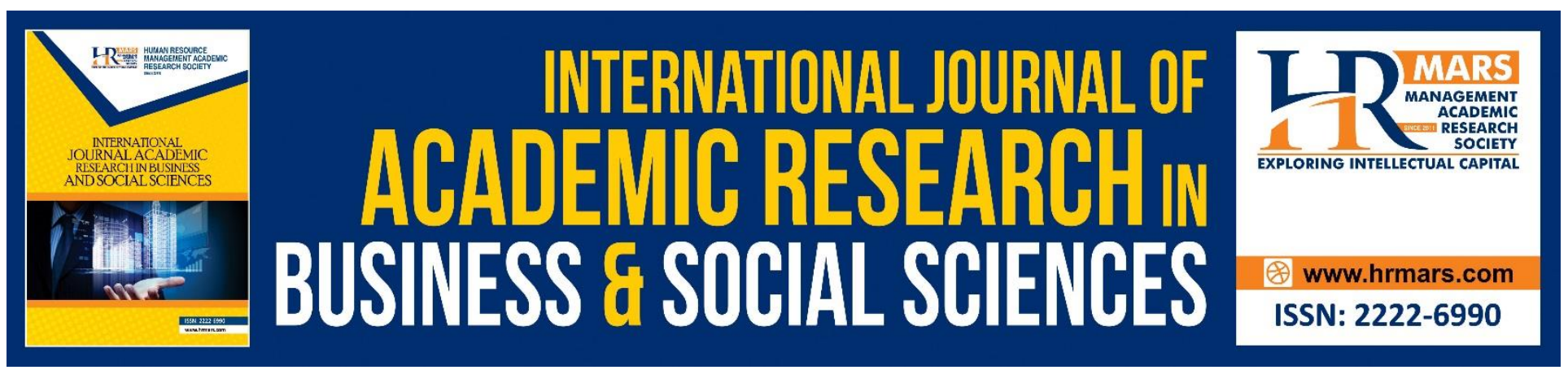

\title{
Assessing Student Teachers' Soft Skills Using Rubrics in E-portfolio
}

\author{
Azliza Muhammad, Othman Lebar, Siti Eshah Mokshein, \\ Razmawaty Mohamed, Salzuriawani Ridzwan \& Laily Fazlin Khairil \\ Faculty of Human Development, Universiti Pendidikan Sultan Idris, 35900 Tanjong Malim, Perak, \\ Malaysia \\ Email: muhammadazliza@gmail.com
}

\begin{abstract}
Technology-based Assessment (TBA) reflects the use of technology as a tool to organize assessment data or the use of technology to conduct an assessment. With progression of technology in the education arena, electronic portfolio (e-portfolio) assessment has emerged to be a growing popular assessment genre to date. In this study, validated rubrics had been used to measure soft skills formatively and continuously through e-portfolio system. The developed and validated rubrics were employed by the students to assess their soft skills upon completing their assignments. This particular study looked into three primary components: (1) rubrics as an assessment tool, (2) e-portfolio system as a technology-based assessment platform, and (3) soft skills assessment as a necessary requisite in becoming a successful education student. Findings showed that students agreed rubrics can be used as assessment tool in the e-portfolio platform to measure their soft skills.
\end{abstract}

\section{Introduction}

According to Durowoju and Onuka (2014), soft skills or generic skills refer to all personality and behavioral traits involving one's personal qualities. Whereas Kechagias (2011) viewed soft skills as intra- and interpersonal (socio-emotional) skills that complement the 'hard skills' of various disciplines. He believed that soft skills are essential for personal development, social participation and workplace success. In fact, the definition of soft skill was described by Fleischmann (2013) through the existence of three components needed that are interaction with others, complementing the role of technical skills and performing tasks more effectively. Futhermore, Ngang dan Chan (2015) agreed that soft skills were the characteristics and skills associated with effective work performance. Furthermore, Ramesh and Mahadevan (2010) underlined that soft skills were built through attitudes, manifested through communication and polished through ethics. These statements was agreed by Attakorn et al. (2014) and Onabamiro, Onuka \& Oyekanmi, (2014) that soft skills were useful for career development and job ethics. All the definitions and usefulness of soft skills aimed at creating 
a positive impact on the job or task when it involves interaction with others. The acquirement of soft skills in teacher education program is no less importance and significant. In Malaysian education context, soft skills are necessity to balance intellectual, spiritual, emotional and physical domain with a firm hold on once faith (Mohd Amin et al., 2013). Previous research had applied few methods to assess soft skills such as performance test (Heckman \& Kautz, 2012), measurement standards (Rasul et al., 2008), performance assessment (DiMartino, Castaneda, Brownstein, \& Miles, 2010) and authentic assessment (Darling-Hammond \& Snyder, 2000). Using e-portfolio assessment as one of the authentic assessment and rubrics as assessment tools in successfully assessing soft skills acquisition had been researched by Hubert \& Lewis (2014), Abdallah et.al (2009) and Swan (2009).

Barrett (2005) highlighted that with e-portfolio, teachers and students can start embedding portfolio artifacts from a variety of media, such as audio and video clips, graphical illustrations, and a wide range of text options. E-portfolio allows the use of hypertext links to present the relevant contents, apart from displaying clear correlations between evidence, standards or goals, artifacts, and reflections. Generally, the e-portfolio is composed of personal details, self and educational philosophies, transcripts, course learning outcomes, artifacts of competence, fieldwork observations, and reflection. The development of an e-portfolio incorporates a whole process of collection, selection, reflection, direction, and celebration or presentation (see Figure 1).

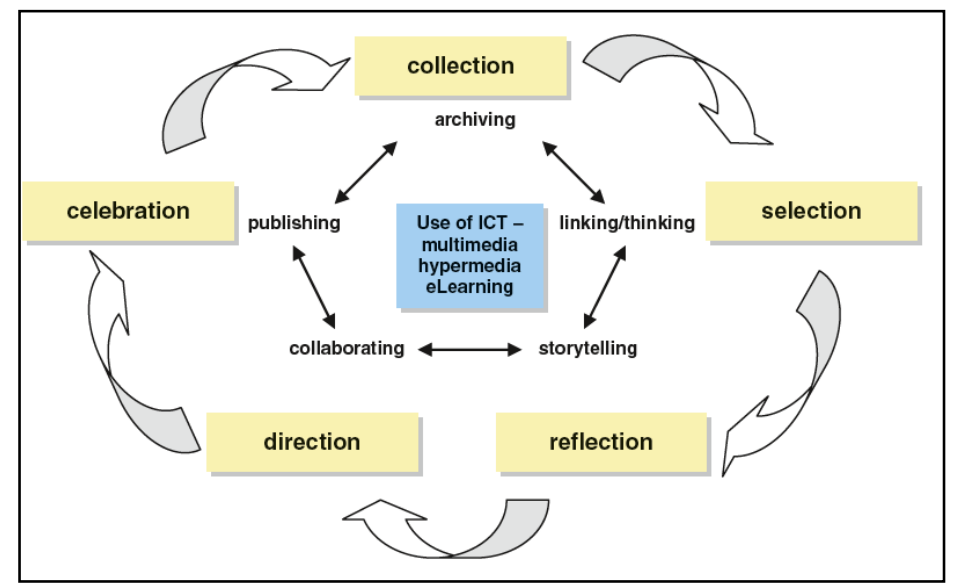

Figure 1: The e-portfolio process with the use of Information and Communications Technology (ICT)

The higher education arena classifies e-portfolios into three types :

i. Student E-Portfolio, which refers to the collection and reflection of student's work.

ii. Teaching E-Portfolio, which is comprised of syllabus, assignments, students' work and assessments, as well as feedback offered by colleagues for improvement.

iii. Institutional E-Portfolio, which contains details of activities, programs, and initiatives from the institution for reflection, learning, and improvement.

The e-portfolios employed in education are listed as follows :

i. Transition e-portfolios, which are used for the transition of a student's development from one institution to another. 
ii. Assessment e-portfolio, in which information, evidence of student's work, and achievements are evaluated based on specific criteria.

iii. Presentation e-portfolio, where students select and communicate evidence with regard to their achievements and personal information.

iv. Learning e-portfolio, where the students can actively engage in the learning process and develop the work that they desire.

Sources: Wyatt-Smith and Cumming (2009), Finger and Jamieson-Proctor (2009), Stefani, Mason, and Pegler (2007)

The e-portfolio assessment is executed via several ways, including formative assessment that incorporates self-assessment, peer assessment, and feedback from teachers or educators. Formative assessment had been used 'all the time' to complement and achieve outcomes in continuous way. Another assessment method reflects the summative assessment that evaluates a student using grades as the yardstick to determine his/her potential in selecting the most suitable course for future undertaking. In this study, the usage of rubrics in e-portfolio creates a framework of assessment eportfolio. Rubrics, functioned as evaluation tool that has a description of the expected performance of the achievement. For researchers such as Churches (2015), rubrics are a systematic way of collecting data on knowledge and skills, while Garfolo et al. (2016) argue that the rubric can also be used to measure certain behaviors. In detail, the rubric is a schema-based questionnaire with selected-response items (Haladyna \& Rogriguez, 2013). The main part of the rubric is the specific expectation or standard of performance to evaluate learning outcomes (Aiken, 1996; Stevens \& Levi, 2013). In short, through e-portfolio assessment in the teaching and learning process, assessment outcomes had been used to make decisions regarding educational improvement in this research, soft skills.

\section{Problem Statement}

A number of studies have displayed that soft skills acquired during teaching training are inadequate, hence calls for enhancement prior to application during their teaching career (Attakorn et al., 2014; Tang, Hashim, \& Yunus, 2015). The present practice adopted by the Universiti Pendidikan Sultan Idris (UPSI) outlines that only lecturers are authorized to assess the aspect of soft skills among students and upload into the Course Learning Outcome Monitoring (CLOM) system (Bahagian Pembangunan Akademik dan Kualiti, 2015). Hence, soft skills are assessed in a summative manner, instead of formative. Formative assessment was found to be more powerful in influencing and giving feedback and reflections on time rather than summative assessment (Hattie \& Timperley, 2007). In fact, Gibb (2004) had once highlighted the variance between soft skills and its correct implementation. This is because; it is challenging for one to modify his/her attitude and behavior to adapt to soft skills when the related lessons are introduced at the end of the course.

\section{Objectives}

As assessment tools, the rubrics developed and validated in this study were applied to meet the following objectives: 
INTERNATIONAL JOURNAL OF ACADEMIC RESEARCH IN BUSINESS AND SOCIAL SCIENCES

Vol. 8, No. 10, Oct. 2018, E-ISSN: 222 2-6990 @ 2018 HRMARS

i. To analyze the level of soft skills among student teachers through e-portfolio assessment.

ii. To determine the most suitable rubric in measuring soft skills through e-portfolio assessment.

\section{Methodology}

Three analytic rubrics had been developed and validated to measure soft skills. The soft skills namely (i) Ability to Practise Active Listening Skills and Give Feedback (KOM2), (ii) Ability to Look For Ideas and Find Alternative Solutions (BKMM3) and (iii) Ability to Analyse and Make Decision in Solving Problem Related to Ethics (EM2). These three soft skills were underlined to be achieved in the Instructional Plan of the Character Development course. The rubrics had underwent content, construct and face validation and reliability analysis. The reliability of Ability to Practise Active Listening Skills and Give Feedback (KOM2), Ability to Look For Ideas and Find Alternative Solutions (BKMM3) and Ability to Analyse and Make Decision in Solving Problem Related To Ethics (EM2) were $0.97,0.93$ and 0.94 while person reliability was $0.86,0.88$ and 0.88 respectively. This was how the rubrics were used to measure student teachers' soft skills using e-portfolio. A total of three assignments had been designated for the Personality Development course, which is a mandatory course in Universiti Pendidikan Sultan Idris (UPSI). Then, the students used the validated rubrics to assess the desired soft skills through three assignment. The assignments are project-based of Experiential Learning (EL), Outreach Program (OP) and the completion of hypothetical issues related to teacher education in Personality Development Module (PDM). After assessing the soft skills using rubrics, the rubrics then been uploaded in the UPSI's e-portfolio system. The interface for the eportfolio assessment system shown in Figure 2.

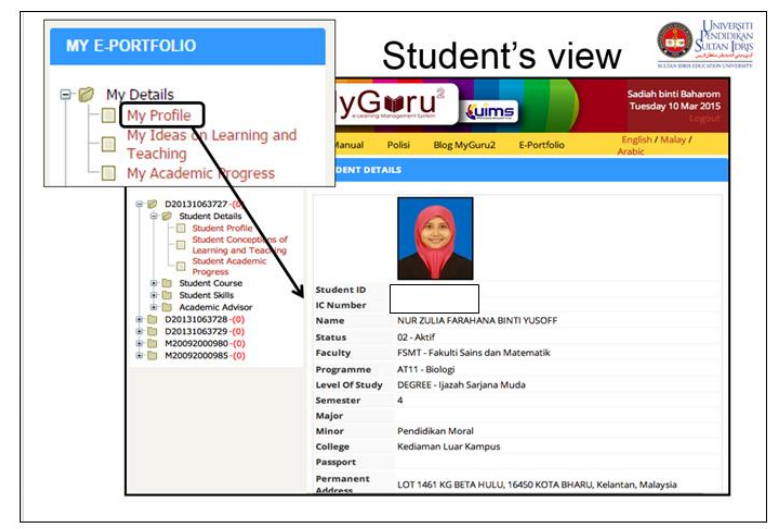

Figure 2: Student's view of UPSI e-portfolio system

From the study, both survey and interview methods had been performed to determine the student teachers' soft skills level and the suitability of the developed rubrics. A total of 41 education students had been selected using purposive sampling for the survey. Next, in order to determine the level of soft skills among the respondents, the stacking method was implemented in the Rasch Measurement model. Individual changes were detailed in the stacking analysis to observe the soft skills changes from:

- Time 1 (Soft Skills Evaluation Assignment - EL) to Time 2 (Soft Skills Evaluation Assignment $\mathrm{OP})$ for KOM2, and 
- Time 1 (Soft Skills Evaluation Assignment - PDM) to Time 2 (Soft Skills Evaluation Assignment - EL) for BKMM3.

A three-week time interval was incorporated between these two assignments. At the end of the semester, 15 education students were selected purposively to participate in a focused group interview to provide feedback on the suitability of using rubrics to measure soft skills through eportfolio.

\section{Results}

i. Determination of Soft Skill's Level Among Student Teachers through E-Portfolio Assessment From the first analysis of determining the soft skill's level among student teachers, codes ' $O$ ' and ' $P$ ' denotes the measurement values for Time 1 (T1) and Time 2 (T2), respectively. The item-person map was developed. Figure 3 illustrates individual measurement for Ability to Practise Active Listening Skills and Give Feedback (KOM2) with improvement observed between the first and the second assignments. As for KOM2, the details are plotted in graph T1 vs T2, as shown in Figure 4.

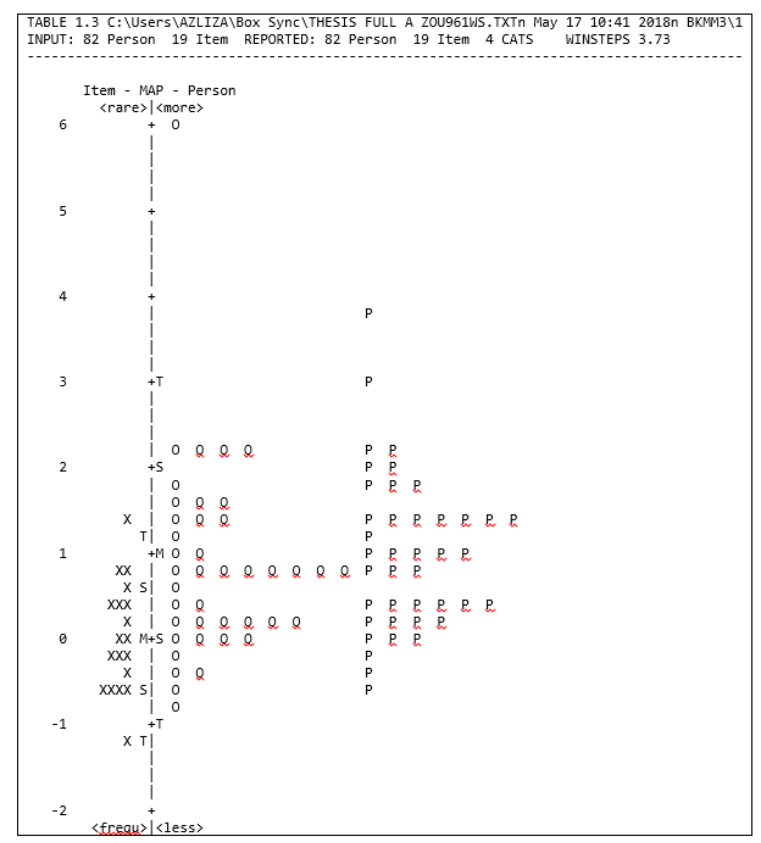

Figure 3: KOM2 Individual Measurement for Experiential Learning (EL) and Outreach 
INTERNATIONAL JOURNAL OF ACADEMIC RESEARCH IN BUSINESS AND SOCIAL SCIENCES

Vol. 8, No. 10, Oct. 2018, E-ISSN: 2222-6990 @ 2018 HRMARS

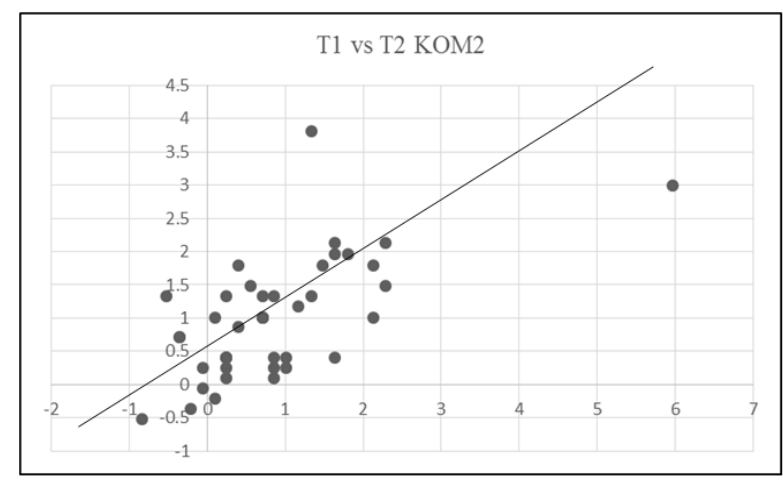

Figure 4: Graph of T1 vs T2 KOM2

Figure 5 portrays the individual measurement for Ability to Look For Ideas and Find Alternative Solutions (BKMM3) with improvement recorded between Assignments 1 and 2. The details are plotted in a graph for both measurements of T1 vs T2, as displayed in Figure 6.

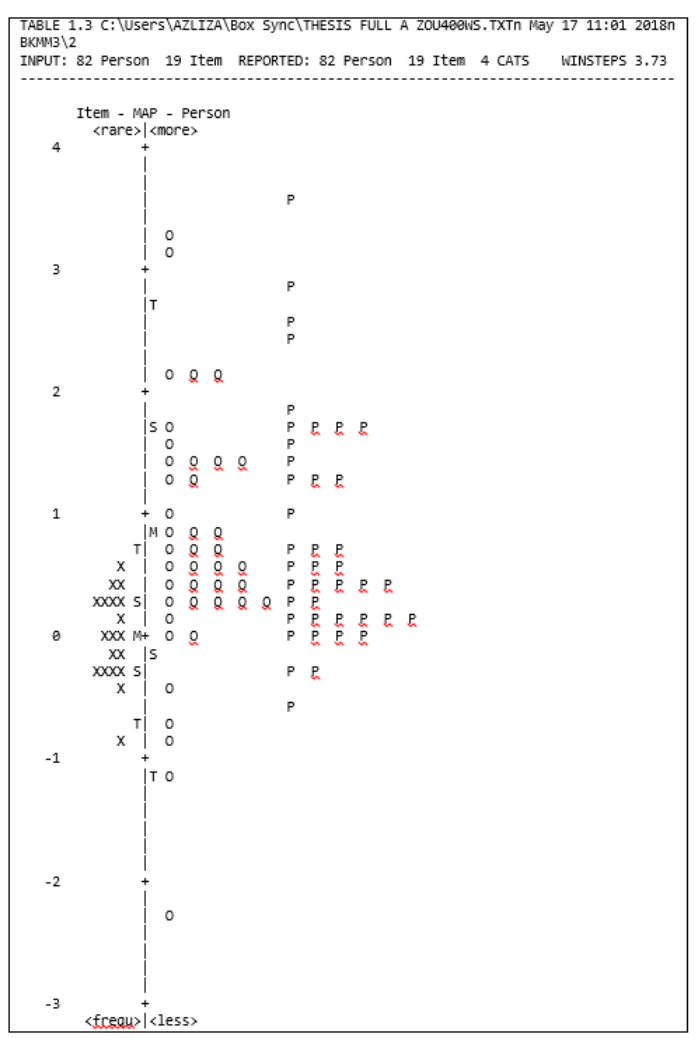

Figure 5: BKMM3 Individual Measurement for Experiential Learning (EL) and Personality Development Module 


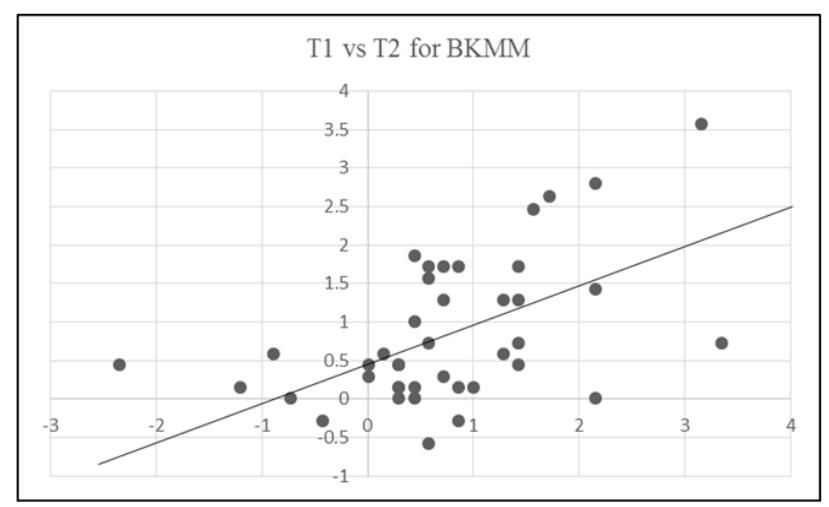

Figure 6: Graph of T1 vs T2 BKMM3

Based on the item-person map and best fit line of T1 versus T2 graphs, the result indicated that there were a slight increase in the level of student teachers' soft skills of Ability to Practise Active Listening Skills and Give Feedback (KOM2) and Ability to Look For Ideas and Find Alternative Solutions (BKMM2). The EM2 soft skill that is ability to analyse and make decision in solving problem related to ethics had not been analysed at this stage because it had been measured only at one point of time.

\section{ii. Suitability of Rubric in Measuring Soft Skills through E-Portfolio Assessment}

Two themes emerged from the interviews conducted that were the role of rubrics as the assessment tools and the use of e-portfolio as the assessment platform. Firstly, rubrics have the element of formative assessment, were also applicable to measure soft skills summatively. Specifically, the rubrics appeared to be suitable to serve as self-assessment tools and support 'self-awareness' and 'self-accountability'. Descriptors in the rubrics had helped in improving specific element of soft skills. The following are feedback given by the respondents:

I reminded myself about evaluating my own self. It was very helpful. I have never thought of the small things that I can actually do up until now, for example, I always interrupt when someone is trying to give information. This has helped me to understand myself better. [S12]

The rubric has helped me in evaluating myself and it is indeed very helpful. For instance, expressing fillers, such as ' $m$ m... ah... owh', is part of the evaluation. A lot of aspects that seem unimportant are actually being looked at and evaluated. Therefore, this assessment is very helpful. I always add the 'ah... and mm...' fillers when I speak. This rubric is very helpful indeed. When I looked at it, I realize that I have a lot of weaknesses, which I have to improve on my soft skills. [ST15]

Secondly, in terms of technology applications, e-portfolio seems suitable because it saves storage space for data and documents. Although technology has power supply and technical constraint, it is still secures the documents in digital forms and the accessing process are easier. The responses on the benefit of e-portfolio as assessment platform are as follows : 
The e-portfolio assessment is indeed a suitable tool. The rubrics are well-kept and the data are secured and safe. If the rubrics are listed on a printed paper, it can easily get wet if it rains. In Myguru, we are given unlimited space, security, and access at any time. When I was in Form 6, I once used Google Drive, but I was not keen because I prefer saving my files in a thumb-drive or hard disk. I have come to acknowledge Google Drive and Dropbox quite early, but back then, I did not realize their benefits. After participating in this study, I now realize the importance of technology and we can utilize them by keeping essential artifacts in the e-portfolio. [ST8]

Artifacts are guaranteed to be safe. It comes in handy since we do not have to think about rain, termites or even if the building catches fire because they are safe. If we log into the e-portfolio, the artifacts will still be there. The rubrics embedded in the e-portfolio serve as a good tool to measure soft skills, which display vast potential for improvement. I am giving it an 8/10. [ST9]

If I were to be a student and my teacher uses e-portfolio, I will definitely be interested to know more about this interesting technology application. Although I have come to realize that there are challenges in using this e-portfolio, it is still a lot better than using papers because we have access to it at any time. Nevertheless, my main concern is when we run out of batteries, but I am pretty sure that we have the solutions. [S8]

From the analysis, it shows that well-developed and validated rubrics can be used to measure soft skills in e-portfolio. Rubrics can be used to improve soft skills among student teachers and e-portfolio can be used to help in self-management.

\section{Conclusion}

As a conclusion, rubrics had been approved as effective self-assessment tool. The learning outcomes displayed some changes in the students' soft skills after they have used the rubrics as an assessment tool. This is vividly illustrated in the plotted graphs that exhibited an increasing trend, as represented by the line of best fit. Concurrently, the students are also exposed to Google Drive as a storage medium that offers links for artifacts and produces artifacts in softcopies by scanning papers using CamScanner. Therefore, the students are not only exposed to e-portfolio or other skills that had been evaluated in Personality Development course but they also are required to master several other essential technological skills. Meanwhile, the focused group discussion portrayed that both knowledge and skills acquired from this study can be applied in the future semesters. The students felt that technology-based documents are more suitable to cater to the needs of the Generation Y. Mastery of the assessment tool is significant to enable its usage at future teaching career. The rubric has been proven to possess high reliability as both measurement and assessment tools, thus making it suitable to be used in achieving learning goals. As such, the students, the faculty, and the university should continuously support in promoting the usage of rubric as an assessment tool in the e-portfolio system. 
INTERNATIONAL JOURNAL OF ACADEMIC RESEARCH IN BUSINESS AND SOCIAL SCIENCES

Vol. 8, No. 10, Oct. 2018, E-ISSN: 222 2-6990 @ 2018 HRMARS

\section{Acknowledgement}

The authors acknowledged the Niche Research Grant Scheme (NRGS) Project (Assessment), Universiti Pendidikan Sultan Idris (2014-00001-107-82-3) and the Ministry of Education Malaysia for the completion of this article.

\section{Corresponding Author}

Azliza Muhammad

Email: muhammadazliza@gmail.com

\section{References}

Abdallah, T., Lansari, A., \& Al-rawi, A. (2009). E-portfolio assessment system for an outcome-based information technology curriculum. Journal of Information Technology Education: Innovations in Practice, 8, 43-54. Retrieved from http://jite.org/documents/Vol8 /JITEv8IIP043054Tubaishat710.pdf

Aiken, L. R. (1996). Rating scales and checklists : evaluating behaviour, personality and attitudes. New York: John Wiley \& Sons,Inc.

Attakorn, K., Tayut, T., Pisitthawat, K., \& Kanokorn, S. (2014). Soft skills of new teachers in the secondary schools of Khon Kaen Secondary Educational Service Area 25, Thailand. In Procedia Social and Behavioral Sciences (Vol. 112, pp. 1010-1013). Elsevier B.V. https://doi.org/10.1016/j.sbspro.2014.01.1262

Bahagian Pembangunan Akademik dan Kualiti. (2015). Course Learning Outcome Monitoring. Retrieved January 1, 2015, from http://bpaq.upsi.edu.my/

Barrett, H. C. (2005). White paper : Researching electronic portfolios and learner engagement : The REFLECT initiative.

Churches, A. (2015). A guide to formative and summative assessment and rubric development. 21st Century Project.

Darling-Hammond, L., \& Snyder, J. (2000). Authentic assessment of teaching in context. Teaching and Teacher Education. https://doi.org/10.1016/S0742-051X(00)00015-9

DiMartino, J., Castaneda, A., Brownstein, M., \& Miles, S. (2010). Authentic assessment. American Book Review, 31(4), 19-19.

Durowoju, E. O., \& Onuka, A. O. U. (2014). Best practices and experiences in soft skills assessment in Oyo Town, Oyo State Schools. Journal of Emerging Trends in Educational Research and Policy Studies (JETERAPS), 5(5), 607-613.

Finger, G., \& Jamieson-Proctor, R. (2009). Assessment issues and new technologies: ePortfolio possibilities. In Educational assessment in the 21st century. Gold Coast: Springer Science+Business Media.

Fleischmann, E. M. (2013). Soft skills of excellent teachers in diverse South African schools in the Western Cape. Stellenbosch University.

Garfolo, B. T., Kelpsh, E. P., Phelps, Y., \& Kelpsh, L. (2016). The use of course embedded signature assignments and rubrics in programmatic assessment. Academy of Business Journal, 8-20.

Gibb, J. (2004). Generic skills in vocational education and training : Research readings. National Centre for Vocational Education Research (NCVER). Adelaide: National Centre for Vocational 
INTERNATIONAL JOURNAL OF ACADEMIC RESEARCH IN BUSINESS AND SOCIAL SCIENCES

Vol. 8, No. 10, Oct. 2018, E-ISSN: 222 2-6990 @ 2018 HRMARS

Education Research (NCVER) Ltd.

Haladyna, T. M., \& Rogriguez, M. C. (2013). Developing and validating test items. New York: Routledge.

Hattie, J., \& Timperley, H. (2007). The power of feedback. Review of Educational Research, 77(1), 81112. https://doi.org/10.1111/j.1365-2923.2009.03542.x

Heckman, J. J., \& Kautz, T. (2012). Hard evidence on soft skills. Labor Economists, 19(4), 451-464. https://doi.org/10.1016/j.labeco.2012.05.014.

Hubert, D. A., \& Lewis, K. J. (2014). A framework for general education assessment : Assessing information literacy and quantitative literacy with ePortfolios, 4(1), 61-71.

Kechagias, K. (2011). Teaching and assessing soft skills. Neapolis: Measuring \& Assessing Soft Skills Project.

Mohd Amin, H., Jaafar, J., Hood, Z., Saad, S., \& Mohd Amin, H. (2013). Kemahiran insaniah pelajar prasiswazah: Analisis perbezaan jantina. Jurnal Teknologi, 61(1), 19-25. https:// doi.org/10.11113/jt.v61.1677

Ngang, T. K., \& Chan, T. C. (2015). The Importance of Ethics, Moral and Professional Skills of Novice Teachers. Procedia - Social and Behavioral Sciences, 205(May), 8-12. https:// doi .org/10.1016/j.sbspro.2015.09.004

Onabamiro, A. T., Onuka, A. O. U., \& Oyekanmi, S. A. (2014). Teachers ' Perception of Teaching and Assessing Soft Skills in Secondary Schools, 4(5), 109-115. https://doi.org /10.5923/j. edu.20140405.01

Ramesh, G., \& Mahadevan, R. (2010). The ACE of soft skills. Attitude, communication and etiquette for success. New Delhi: Dorling Kindersley.

Rasul, M. S., Ismail, M. Y., Ismail, N., Rajuddin, M. R., \& Rauf, R. A. A. (2008). Pembangunan standard pengukuran kemahiran "employability." Jurnal Teknologi, 49, 15-30.

Stefani, L., Mason, R., \& Pegler, C. (2007). The educational potential of e-portfolios. Supporting personal development and reflective learning. Oxon: Routledge.

Stevens, D. D., \& Levi, A. J. (2013). Introduction to rubrics. Stylus Publishing (2nd ed.). Sterling.

Swan, G. (2009). Examining barriers in faculty adoption of an e-portfolio system. Australasian Journal of Educational Technology, 25(5), 627-644.

Tang, K. N., Hashim, N. H., \& Yunus, H. M. (2015). Novice Teacher Perceptions of the Soft Skills Needed in Today's Workplace. Procedia - Social and Behavioral Sciences, 177(July 2014), 284-288. https://doi.org/10.1016/j.sbspro.2015.02.338

Wyatt-Smith, C., \& Cumming, J. J. (2009). Educational assessment in the 21st century. Connecting theory and practice. New York: Springer. 